\title{
PIGMENT AND ACYL LIPID COMPOSITION OF PHOTOSYSTEM I AND II VESICLES AND OF PHOTOSYNTHETIC MUTANTS IN BARLEY
}

by

\author{
LANDIS E.A. HENRY, JØRN DALGAARD MIKKELSEN and \\ BIRGER LINDBERG MØLLER
}

Department of Physiology, Carlsberg Laboratory,

Gamle Carlsberg Vej 10, DK-2500 Copenhagen Valby

Keywords: Oxygen evolving photosystem II vesicles, stroma lamellae, inside-out vesicles, reversed-phase high performance liquid chromatography, thin-layer chromatography, spinach, viridis-z $b^{63}$, viridis- $z d^{69}$, chlorina- $f 2$, trans-3-hexadecenoic acid

The pigment and acyl lipid composition of photochemically active stroma lamellae and inside-out photosystem II vesicles have been investigated. Mechanical disruption followed by phase partitioning in an aqueous two phase system resulted in a clean separation of the photosystems. A qualitative and quantitative determination of the pigment content was achieved using reversed-phase high performance liquid chromatography. A single chromatographic separation provided adequate resolution of neoxanthin, violaxanthin, lutein, chlorophyll $b$, chlorophyll $a$, and $\beta$-carotene and was completed in $22 \mathrm{~min}$. For each molecule of $P 700$, the stroma lamellae contained 166 molecules of chlorophyll $a, 14$ molecules of chlorophyll $b, 0$ molecules of neoxanthin, 3 molecules of violaxanthin, 7 molecules of lutein, and 13 molecules of $\beta$-carotene. For each molecule of $P 680$ the photosystem II vesicles contained 250 molecules of chlorophyll $a, 100$ molecules of chlorophyll $b, 7$ molecules of neoxanthin, 7 molecules of violaxanthin, 22 molecules of lutein, and 4 molecules of $\beta$-carotene. The pigment content of three photosynthetic mutants chlorina- $f 2$, viridis-z $b^{63}$ and viridis-z $d^{69}$ was determined. On a chlorophyll basis, these mutants generally showed a reduced carotenoid content, except that chlorina- $f 2$ had an increased level of $\beta$-carotene and viridis-z $d^{69}$ an unaltered level of lutein.

The acyl lipid composition of stroma lamellae, photosystem II vesicles and lamellar systems was also determined. Although the photochemical activities of the stroma lamellae and photosystem II vesicles were enriched compared to the parent lamellar system, more than $50 \%$ of the acyl lipids in the subchloroplastic membranes were degraded or severely modified resulting in a drastically reduced content of monogalactosyldiglyceride and digalactosyldiglyceride in the stroma lamellae and photosystem II vesicles. Due to the lipolytic degradation the level of saturation in the galactolipids was higher in stroma lamellae and photosystem II vesicles compared with the lamellar system. Stroma lamellae do not contain the light-harvesting chlorophyll $a / b$-protein, but were enriched in phosphatidylglycerol and trans-3-hexadecenoic acid.

Abbreviations: $\mathrm{Chl}=$ chlorophyll; $\mathrm{Chl}-\mathrm{P}=$ chlorophyll-protein $; \mathrm{DG}=$ digalactosyl diglyceride $; \mathrm{GLC}=$ gas-liquid chromatography; HPLC = high-performance liquid chromatography; $\mathrm{MG}=$ monogalactosyldiglyceride; $\mathrm{PC}=$ phosphatidylcholine; $\mathrm{PG}=$ phosphatidylglycerol; $\mathrm{PI}=$ phosphatidylinositol; $\mathrm{SL}=$ sulfoquinovosyldiglyceride; TLC $=$ thin layer chromatography. 


\section{INTRODUCTION}

Unique sets of polypeptides characterize the grana membranes containing photosystem II (4, $10,27,28,38,39,72)$ and the stroma lamellae containing photosystem I together with the coupling factor $(9,27,40,41,42)$. There are indications that the individual pigments and acyl lipids of the thylakoids are likewise specifically associated with certain membrane fractions and individual membrane proteins. Among the different pigments, the association of chlorophyll $a$ and $b$ with specific proteins is the best documented. Five different thylakoid polypeptides are known to bind chlorophyll $a$, namely chlorophyll $a$-proteins 1, 2, and 3, and chlorophyll $a /$ $b$-proteins 1 and 2. Chlorophyll $a$-protein 1 contains the reaction center of photosystem I whereas chlorophyll $a$-proteins 2 and 3 are associated with photosystem II, chlorophyll $a$-protein 3 carrying the $P 680$ reaction center (35). Of these chlorophyll-proteins, chlorophyll $a$-protein 1 is restricted to the stroma lamellae including the unappressed membranes of the grana stacks, whereas the remaining two chlorophyll $a$-proteins and the two chlorophyll $a / b$-proteins are localized in the grana stacks (27). The accessory pigment chlorophyll $b$ is bound exclusively to chlorophyll $a / b$-proteins 1 and $2(2,14,17,35,49$, 66 ). In the absence of chlorophyll $b$, these chlorophyll-proteins cannot accumulate in the thylakoid membrane (35). $\beta$-Carotene is enriched in stroma lamellae and is thought to be a component of chlorophyll $a$-protein 1 (9). However, a specific function of $\beta$-carotene in photosystem II has also been implicated $(33,45,56)$ and $\beta$-carotene is enriched in the chlorophyll $a$-proteins associated with photosystem II (49). Chlorophyll $a / b$-protein 2 binds the xanthophylls lutein, neoxanthin, and violaxanthin (52). The association of xanthophylls with other specific thylakoid polypeptides has not been established. Overall, the quantitative data available on the association of pigments with isolated thylakoid polypeptides show a great variation $(9,15,49,52,66)$.

The acyl lipid composition of thylakoids, chlorophyll $a / b$-protein 2 and of chlorophyll $a$ protein 1 have likewise been studied. Whereas the reported values for the lamellar systems are comparable $(22,52)$, the acyl lipid content of isolated thylakoid polypeptides show a considerable variation $(49,52,67,68,69)$.

Quantitation of the pigments and acyl lipids associated with specific membrane fractions and individual membrane proteins has thus proved difficult. This is partially because the preparative procedures used have resulted in preparations differing in their polypeptide composition and which therefore are not suitable for comparison. Secondly, in those cases where the polypeptide composition could have been identical, a differential displacement of a variable number of the non-covalently bound pigment and acyl lipid molecules by detergent molecules may have resulted from the different procedures. The extent of this displacement is dependent on the type and the concentration of the detergent used, duration of incubation, temperature and other experimental factors which all together are difficult to reproduce in different laboratories. Information about the in vivo association of pigments and acyl lipids with specific membrane fractions is therefore best studied in the absence of detergents. In the present investigation the pigment and acyl lipid composition of stroma lamellae and inside-out photosystem II vesicles prepared by an improved fractionation procedure avoiding the use of detergents was studied in addition to the pigment content of three photosynthetic mutants lacking specific thylakoid polypeptides.

\section{MATERIALS AND METHODS}

\subsection{Biological Preparations}

Seedlings of wild-type barley (Hordeum vulgare L. cv. Svalöf's Bonus) and of the recessive photosynthetic mutants chlorina- $f 2$, viridis- $z b^{63}$ and viridis- $z d^{69}(62)$ were grown for 7 days in vermiculite using continuous illumination (1700 lux). Spinach plants (Spinacia oleracea L.) were imported from Italy. Stroma lamellae and insideout photosystem II vesicles with retained oxygen evolving capacity were prepared from chloroplast lamellar systems of spinach (27). Comparable although slightly less clean preparations were obtained from wild-type barley when the following modifications were used: The stacked lamellar systems were passed three times through the French Pressure Cell at a pressure of 3,600 lb.in ${ }^{-2}$. The grana enriched fraction obtained by centrifugation was resuspended in a medium 
composed of $100 \mathrm{~mm}$-sucrose, $5 \mathrm{~mm}-\mathrm{NaCl}$ and $10 \mathrm{~mm}$-sodium phosphate $(\mathrm{pH} 7.4)$ and further fragmented by two additional treatments in the French Pressure Cell at a pressure of 3,000 lb.in-2. The subsequent phase separation of the membrane vesicles, was carried out at polyethylene glycol and dextran concentrations of $6.02 \%(w / w)$. To obtain a pure photosystem II preparation, successive repartitioning of the lower dextran phase was continued until a colourless top phase was obtained. This routinely required five partitionings.

Light harvesting chlorophyll $a / b$-protein 2 was prepared from barley thylakoids essentially as described in (15).

\subsection{Extraction of lipids}

Aliquots $(0.5 \mathrm{ml})$ of lamellar systems or fractionated membranes containing $250 \mu \mathrm{g}$ chlorophyll were extracted with $0.9 \mathrm{ml}$ of a mixture of chloroform:methanol (53:37 (v/v)) (49). The extraction was carried out in tubes with teflonlined stoppers by thorough shaking on a Vortex mixer for $3 \mathrm{~min}$. The insoluble protein residue was recovered by centrifugation $(3,500 \mathrm{~g}$ for 5 $\mathrm{min}$ ) and re-extracted an additional four times in chloroform/methanol and finally in chloroform. The combined chloroform phases were analysed directly or after concentration. All extractions were carried out in the dark at room temperature using redistilled solvents.

\subsection{Thin-layer chromatography of pigments}

Pigments were separated by TLC on precoated (200 $\mu \mathrm{m}$ thickness) reversed-phase $\mathrm{C}-18$ silica plates $(20 \mathrm{~cm} \times 20 \mathrm{~cm})$ (Whatman Inc., New Jersey, USA). The plates were developed in the dark using methanol/ethylacetate/water $(56: 30: 14$ or $40: 50: 10(\mathrm{v} / \mathrm{v} / \mathrm{v}))$ as the mobile phase. The developed plate was dried in a stream of nitrogen before the pigment containing bands were scraped off and the pigments extracted with ethanol. The pigment standards were quantified using their absorption characteristics in conjunction with extinction coefficients from the literature $(18,73)$.

\subsection{High-performance liquid chromatography}

Analyses were performed using a Waters Assoc. (Milford, Mass., USA) instrument com- posed of two Model $6000 \mathrm{~A}$ solvent delivery systems, a WISP 710B automatic injector, a Model 450 variable wavelength detector, a Data Module and a System Controller. All separations were carried out by the use of a prepacked $\mu$ Bondapak C-18 (10 $\mu \mathrm{m}$ particle size) "Radial Pack Cartridge" $(10 \mathrm{~cm} \cdot 0.8 \mathrm{~cm}$ i.d.) equipped with an RC SS Guard-Pak C-18 (37-50 $\mu \mathrm{m}$ particle size) pre-column $(0.8 \mathrm{~cm} \cdot 0.5 \mathrm{~cm}$ i.d.). Both the column and the pre-column were fitted into Radial Compression Module RCM-100. Elution of the pigments was carried out using a multistep gradient composed of methanol and increasing concentrations of ethyl acetate: The initial conditions were $100 \%$ methanol. The ethyl acetate concentration was then increased linearly to $15 \%$ during the first $10 \mathrm{~min}$. Over the next $3 \mathrm{~min}$, the concentration of ethyl acetate was raised to $35 \%$. During a subsequent 7 min period, the ethyl acetate concentration was further increased to $100 \%$, where it was kept constant for an additional $5 \mathrm{~min}$. The chromatography was carried out at $20^{\circ} \mathrm{C}$ and the solvent flow rate was 1.0 $\mathrm{ml} \cdot \mathrm{min}^{-1}$. The elution of pigments was monitored spectrophotometrically at $430 \mathrm{~nm}$. The chromatographic parameters of the pigment standards were determined by injecting these individually or in mixtures of known composition into the HPLC instrument. The peak observed upon injection of a known pigment standard was automatically integrated and a calibration curve was constructed for each pigment by plotting the peak area monitored at $430 \mathrm{~nm}$ against the concentration of the standard.

\subsection{Acyl lipid analyses}

Lipid extracts were dried under a stream of $\mathrm{N}_{2}$ and redissolved in a small volume of chloroform. The various lipid classes were separated by TLC using precoated silica plates (Type 60, F254, Merck, Darmstadt, F.R.G.) with acetone/benzene $/ \mathrm{H}_{2} \mathrm{O}(90: 30: 8,(\mathrm{v} / \mathrm{v} / \mathrm{v}))$ as developing solvent (47).

The separated lipid bands were visualized by spraying the plates with a solution of $0.2 \% 8$ anilino naphthalene sulfonic acid in methanol and subsequent examination of the plates in u.v. light $(260 \mathrm{~nm})(60)$. The various lipid classes were identified by determining their chromatographic mobilities in an additional three 
solvent systems: chloroform/methanol/acetic $\mathrm{acid} / \mathrm{H}_{2} \mathrm{O}(85: 15: 10: 3,(\mathrm{v} / \mathrm{v} / \mathrm{v} / \mathrm{v}))$, chloroform/ methanol $/ \mathrm{H}_{2} \mathrm{O}(65: 23: 4,(\mathrm{v} / \mathrm{v} / \mathrm{v}))$, and hexane/ acetone $(60: 40,(\mathrm{v} / \mathrm{v}))(49,60)$. The identifications were substantiated using specific colour tests obtained by spraying the TLC plates with Chargaff's reagent, diphenylamin, ninhydrin or sulphuric acid in methanol $(35: 65,(\mathrm{v} / \mathrm{v}))(60$, 70).

The fatty acid composition of individual lipid classes was determined by carefully scraping off the appropriate lipid zone from the TLC plate. After transesterification at $85{ }^{\circ} \mathrm{C}$ for 2 hours using $5 \% \mathrm{H}_{2} \mathrm{SO}_{4}$ in methanol $(\mathrm{v} / \mathrm{v})$, the methyl esters formed were recovered from the reaction mixture by three repeated hexane extractions (60). Pentadecanoic acid was used as an internal standard during transesterification and gas-liquid chromatography (GLC). The GLC analyses were performed with a Hewlett Packard Model 5840A instrument (Hewlett Packard, Avondale, $\mathrm{Pa}$., USA) fitted with a flame ionization detector and a stainless steel column $(244 \mathrm{~cm} \cdot 0.2 \mathrm{~cm})$ packed with $10 \%$ Silar 10C on 100-120 mesh Gas Chrom Q (Applied Science, Penn., USA) (7). Chromatographic separation was obtained by increasing the temperature of the oven from $150^{\circ} \mathrm{C}$ to $190^{\circ} \mathrm{C}$ at a rate of $3{ }^{\circ} \mathrm{C} \cdot \mathrm{min}^{-1}$. The injection port and detector were operated at 220 and 350 ${ }^{\circ} \mathrm{C}$, respectively. The flow rate of the carrier gas $\left(\mathrm{N}_{2}\right)$ was $20.6 \mathrm{ml} \cdot \mathrm{min}^{-1}$. The GLC was calibrated with methyl palmitate according to NETTING and BARR (43). Quantitation of the acyl lipids as their methyl esters were performed using flame ionization detector response factors of $15.75,15.70,17.75,17.70,17.65$ and 17.60 for the methyl esters of $16: 0,16: 1,18: 0,18: 1,18: 2$ and $18: 3$, respectively (63).

\subsection{Preparation of pheophytin $a$ and $b$}

Pheophytin $a$ and $b$ were prepared by dissolving the corresponding chlorophyll in $85 \%$ methanol. The solutions were acidified by the addition of oxalic acid and thereafter neutralized with sodium hydroxide (64). The removal of magnesium from the chlorophylls was monitored by absorption spectroscopy.

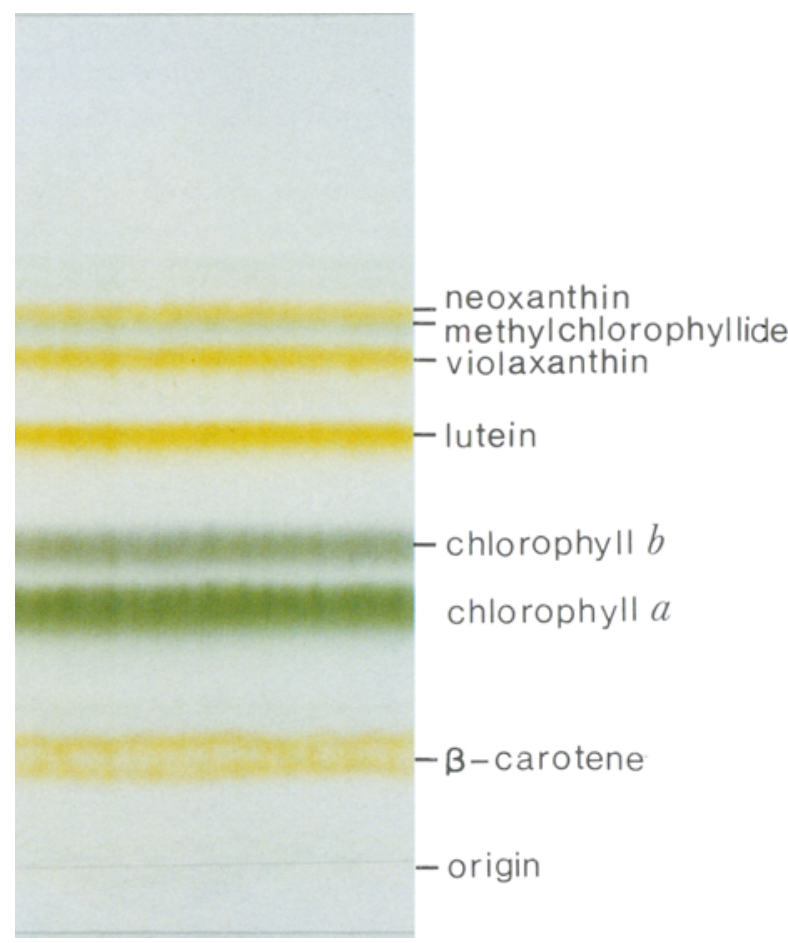

Figure 1. Thin layer chromatographic analysis of the pigment extract from spinach thylakoids.

Separation was carried out on a $\mathrm{C}_{18}$ reversed phase silica thin-layer plate developed in ethyl acetate $/ \mathrm{me}$ thanol $/ \mathrm{H}_{2} \mathrm{O}(50: 40: 10 \mathrm{v} / \mathrm{v} / \mathrm{v})$.

\section{RESULTS}

\subsection{Preparation of pigment standards from spinach}

The principal in vivo pigments of spinach thylakoids are well separated by reversed-phase thin-layer chromatography using methanol/ water/ethyl acetate $(40: 10: 50(\mathrm{v} / \mathrm{v} / \mathrm{v}))$ as solvent (Figure 1). The pigment bands were identified by comparison of chromatographic behavior and room temperature absorption spectra (Table I) with known pigment standards $(18,31,73)$. As expected, the pigments ascended in order of increasing polarity: neoxanthin, the most polar component, had the highest mobility, and $\beta$-carotene, the most hydrophobic component, the lowest. The faint green pigment band observed between violaxanthin and neoxanthin is thought to be methyl chlorophyllide $a(59)$ formed during the methanol extraction by the action 
L. E. A. HENRY et al.: Lipid analyses of photosynthetic membranes.

Table I.

Main absorption maxima of pigments dissolved in ethanol.

\begin{tabular}{llll}
\hline Pigment & \multicolumn{3}{c}{$\begin{array}{c}\text { Main absorption maxima (nm) } \\
\text { in ethanol }\left(20^{\circ} \mathrm{C}\right)\end{array}$} \\
\hline neoxanthin & 414 & 437.5 & 466 \\
violaxanthin & 418 & 442.5 & 471 \\
lutein & 422.5 & 446.5 & 474 \\
chlorophyll $b$ & 465 & & 649 \\
pheophytin $b$ & 445 & & \\
chlorophyll $a$ & 432 & & 666 \\
pheophytin $a$ & 411 & & \\
$\beta$-carotene & 426 & 450 & 476 \\
\hline
\end{tabular}

of chlorophyllase (16). Rechromatography of the individual components in solvent systems of different polatities did not resolve any additional components.

\subsection{High performance liquid chromatography}

A model pigment system composed of the pigment standards neoxanthin, violaxanthin, lutein, $\beta$-carotene and chlorophylls $a$ and $b$ isolated as described in section 3.1 was used to test a series of different solvent systems. The mobile phase found to be most suitable for the separation of the test sample was varying ratios of methanol and ethyl acetate (Table II).

With the exception of chlorophyll $a$, all pigment standards injected into the HPLC gave a single symmetrical peak. The chlorophyll $a$ standard was routinely resolved into two peaks ( $\mathrm{K}^{1}$ 2.38 and 2.85 ) with the more polar component

Table II.

Separation of chlorophylls and carotenoids by reversed-phase HPLC.

\begin{tabular}{lc}
\hline Pigment & $\begin{array}{c}\text { Capacity Factor a) } \\
\left(\mathrm{K}^{1}\right)\end{array}$ \\
\hline neoxanthin & 0.44 \\
violaxanthin & 0.67 \\
lutein & 1.22 \\
chlorophyll $b$ & 1.82 \\
chlorophyll $a$ & 2.85 \\
3-carotene & 5.46 \\
\hline
\end{tabular}

a) The capacity factor $K 1$ is defined by the equation $K 1$ $=\left(t_{r}-t_{0}\right) / t_{o}$ where $t_{r}$ is the time from injection to peak maximum and $t_{o}$ is the time from injection to the first deflection observed using an unretained reference compound.

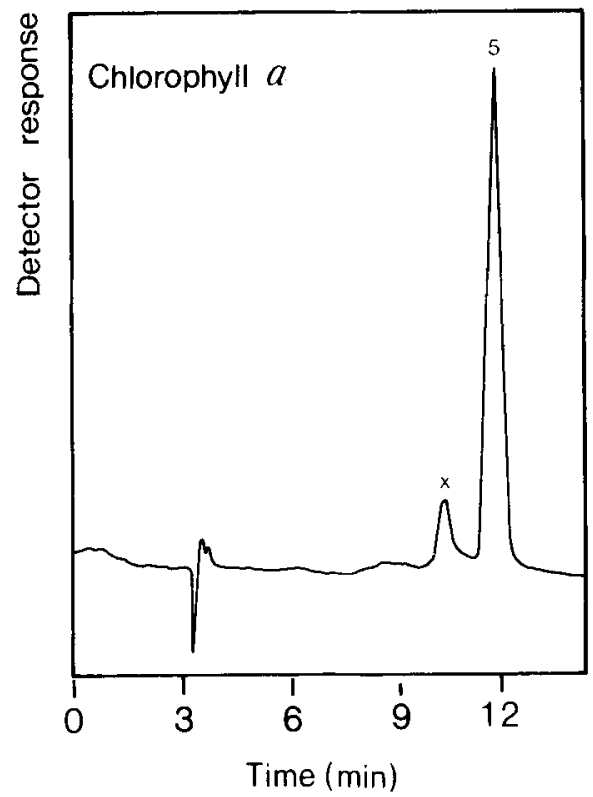

Figure 2. High performance liquid chromatogram of chlorophyll $a$ standard prepared by thin-layer chromatography.

Peak X represents a more polar component which has spectral parameters identical to the principal chlorophyll a peak (5) and which is thought to be 10hydroxy chlorophyll $a$. Detector sensitivity was 0.2 absorbance units and the effluent was monitored at a wavelength of $430 \mathrm{~nm}$. Other chromatographic conditions are described under section 2.4 .

constituting approximately $15 \%$ of the total (Figure 2). The room temperature absorption spectra were identical for both components. The spectral properties and the chromatographic behaviour suggest that this polar component is 10 hydroxy-chlorophyll $a$ which is easily formed from chlorophyll a upon exposure to air (64). Pheophytin $a$ and $b$ were observed in samples incubated at room temperature under continuous illumination.

\subsection{Pigment analysis of photosystem II vesicles and of photosystem I containing stroma lamellae vesicles}

The pigment profiles of lamellar systems, photosystem II vesicles, and photosystem I containing stroma lamellae vesicles are indicated on Figure 3. An additional component slightly less polar than neoxanthin was sometimes observed in aged extracts of the lamellar systems. This 
L. E. A. HENRY et al.: Lipid analyses of photosynthetic membranes.
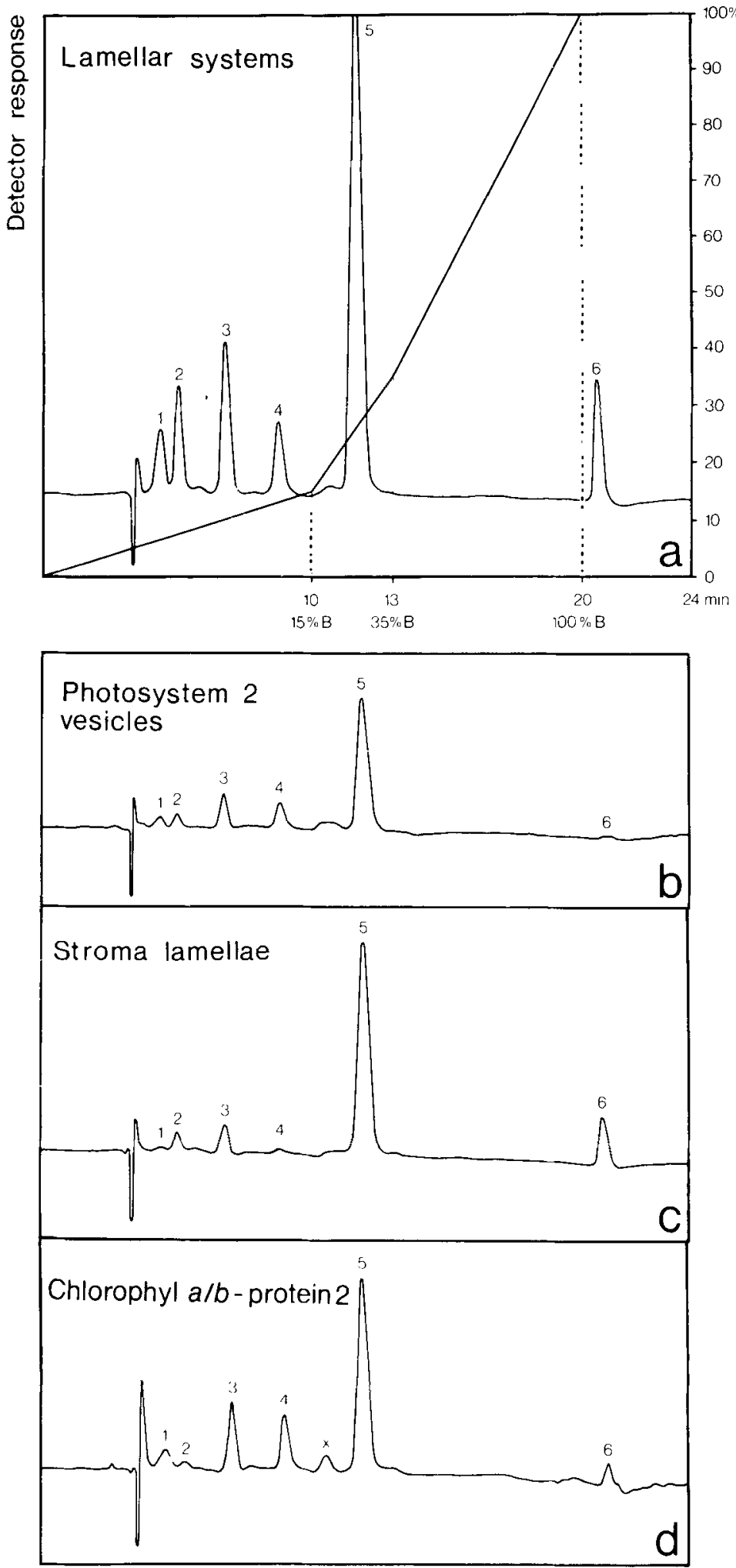

Time $(\min )$ 
Figure 3. High performance liquid chromatograms of the pigments in barley lamellar systems, photosystem II vesicles, photosystem I containing stroma lamellae vesicles, and chlorophyll $a / b$-protein 2 .

1 = neoxanthin, 2 = violaxanthin, $3=$ lutein, 4 = chlorophyll $\mathrm{b}, \mathrm{X}=$ tentatively identified as 10 -hydroxy chlorophyll $a, 5=$ chlorophyll $a$, and $6=\beta$ - carotene. Separation was carried out using a methanol (A)/ ethyl acetate (B) gradient. The gradient profile is indicated on Figure $3 a$ as $\%$ of solvent $B$. In the analysis of the lamellar systems, the detector sensitivity was set at 0.1 absorbance units full scale, in the other cases it was set at 0.2 . Other chromatographic conditions as described in section 2.4 .

component was tentatively identified as methyl chlorophyllide $a$. Pheophytins were observed in chlorophyll samples stored at room temperature under constant illumination.

The pigment composition of the various fractions expressed as molecules of the individual pigments per 1000 molecules of chlorophyll is presented in Table III. The pigment composition of the lamellar systems of barley and spinach are almost identical (Table III) and compares well with the pigment composition reported for spinach (52). Comparison of the pigment composition of the photosystem II vesicles with the stroma lamellae revealed 5-6 fold enrichment of $\beta$-carotene in the stroma lamellae vesicles. In contrast, lutein was enriched in the photosystem II vesicles. Photosystem II vesicles, lamellar sys- tems, and stroma lamellae vesicles (Table III) also showed increasing order of chlorophyll $a / b$ ratios as reported in the literature $(11,53,71)$. The unit size of the two photosystems are different. Whereas the chlorophyll/P700 ratio of the stroma lamellae is 180 (determined by difference spectroscopy), the chlorophyll/P680 ratio of the photosystem II inside-out vesicles is about 350 (determined from the fluorescence induction transient in the presence of 3-(3',4'-dichlorophenyl)-1, l-dimethyl urea (DCMU)). Based on these values the number of pigment molecules present per reaction center in the two preparations can be calculated (Table IV). Chlorophyll $b$ is thought to be bound exclusively to chlorophyll $a / b$-proteins 1 and $2(2,35)$. Electrophoretic analysis suggests that the amount of chlorophyll $b$ associated with chlorophyll $a / b$ protein 1 is of little quantitative importance (35). Isolated chlorophyll $a / b$-protein 2 (15) was found to bind a maximum of 7 molecules chlorophyll $a$ and 6 molecules chlorophyll $b$ (Tabie V). The 14 molecules of chlorophyll $b$ present in the photosystem I preparation per $P 700$ reaction center and the 100 molecules of chlorophyll $b$ in the photosystem II preparation per molecule of $P 680$ would thus suggest the presence of 2 and 17 molecules of chlorophyll $a / b$-protein 2 per molecule of $P 700$ and $P 680$, respectively. Although some of the chlorophyll $a$-protein 1 molecules may not carry $P 700$, the above calculation is clearly not in agreement with the SDS-PAGE

Table III.

Pigment composition of photosystem II vesicles and stroma lamellae vesicles from barley and spinach.

\begin{tabular}{|c|c|c|c|c|c|c|c|}
\hline \multirow[t]{2}{*}{ Plant } & \multicolumn{7}{|c|}{ Pigment (molecules of pigment/1000 molecules of chlorophyll) } \\
\hline & $\begin{array}{c}\text { neoxan- } \\
\text { thin }\end{array}$ & $\begin{array}{c}\text { violaxan- } \\
\text { thin }\end{array}$ & lutein & $\begin{array}{l}\text { chloro- } \\
\text { phyll } b\end{array}$ & $\begin{array}{l}\text { chloro- } \\
\text { phyll } a\end{array}$ & $\begin{array}{c}\beta- \\
\text { carotene }\end{array}$ & $\operatorname{chl} a / b$ \\
\hline \multicolumn{8}{|l|}{ BARLEY } \\
\hline lamellar systems & 39 & 43 & 70 & 215 & 785 & 65 & 3.65 \\
\hline photosystem II vesicles & 20 & 20 & 64 & 285 & 714 & 12 & 2.51 \\
\hline chlorophyll $a / b$-protein 2 & 26 & 5 & 93 & 383 & 617 & 31 & 1.61 \\
\hline stroma lamellae vesicles & $<5$ & 19 & 40 & 80 & 920 & 77 & 11.5 \\
\hline \multicolumn{8}{|l|}{ SPJNACH } \\
\hline lamellar systems & 38 & 43 & 68 & 202 & 798 & 66 & 3.95 \\
\hline photosystem II vesicles & $<5$ & 12 & 56 & 292 & 708 & 16 & 2.42 \\
\hline stroma lamellae vesicles & $<5$ & 26 & 36 & 109 & 891 & 84 & 8.17 \\
\hline lamellar systems a) & 34 & 41 & 110 & 262 & 737 & 76 & 2.81 \\
\hline
\end{tabular}

a) data calculated from ( 52$)$ 
L. E. A. HENRY et al.: Lipid analyses of photosynthetic membranes.

Table IV.

Pigment content of the photosynthetic unit in photosystem II vesicles and photosysten I containing stroma lamella vesicles of barley.

\begin{tabular}{lccccccccc}
\hline & $P 680$ & $P 700$ & $\begin{array}{c}\text { total } \\
\text { chl }\end{array}$ & $\operatorname{chl} a$ & $\operatorname{chl} b$ & $\begin{array}{c}\text { neoxan- violaxan- } \\
\text { thin } \\
\text { thin }\end{array}$ & lutein $\begin{array}{c}\beta- \\
\text { carotene }\end{array}$ \\
\hline Stroma lamellae vesicles & 0 & 1 & 180 & 166 & 14 & 0 & 3 & 7 & 13 \\
Photosystem II vesicles & 1 & 0 & 350 & 250 & 100 & 7 & 7 & 22 & 4 \\
\hline
\end{tabular}

profiles of the stroma lamellae which show an intense Coomassie Brilliant Blue band corresponding to chlorophyll $a$-protein 1 but no band corresponding to chlorophyll $a / b$-protein $2(27)$. Similarly, the photosystem II preparation does not seem to contain that high amounts of chlorophyll $a / b$-protein 2 compared to chlorophyll $a$ protein 3 (27). This apparent discrepancy can be explained if it is postulated that the chlorophyll $a / b$-protein 2 in vivo binds a much larger number of chlorophyll $a$ and $b$ molecules, which, however, upon isolation of the protein are lost Secondly, the ratio of chlorophyll $a$ to $b$ may vary in chlorophyll $a / b$-protein 2 . The stroma lamellae vesicles showed no photosystem II activity, nor variable fluorescence $(77 \mathrm{~K})$. This excludes that the chlorophyll $b$ present in the stroma lamellae vesicles is a contaminant derived from the appressed regions. It also excludes the chlorophyll $b$ as a part of an active photosystem II particle localized in the stroma lamellae.

Table $\mathrm{V}$.

Literature data on the pigment content of isolated chlorophyll-proteins

\begin{tabular}{|c|c|c|c|c|c|c|c|c|c|}
\hline \multirow[t]{2}{*}{ Plant material } & \multirow[t]{2}{*}{ Isolation method } & \multirow{2}{*}{$\begin{array}{c}\text { total } \\
\text { chloro- } \\
\text { phyll }\end{array}$} & \multicolumn{6}{|c|}{ Pigment (moles of pigment/mole of protein) } & \multirow[t]{2}{*}{ reference } \\
\hline & & & $\begin{array}{l}\text { neox- } \\
\text { anthin }\end{array}$ & $\begin{array}{l}\text { violax- } \\
\text { anthin }\end{array}$ & lutein & $\begin{array}{l}\text { chloro- } \\
\text { phyll } b\end{array}$ & $\begin{array}{l}\text { chloro- } \\
\text { phyll } a\end{array}$ & $\begin{array}{l}\beta \text {-car- } \\
\text { otene }\end{array}$ & \\
\hline \multicolumn{10}{|c|}{ Chlorophyil $a / b$-protein 2} \\
\hline Spinach & $\begin{array}{l}\text { Triton, sucrose } \\
\text { gradient, } \\
\text { Mg-precipitation }\end{array}$ & 6.8 & .57 & .26 & 1.0 & 3.1 & 3.7 & .05 & $(52)$ \\
\hline Pea & $\begin{array}{l}\text { Triton, sucrose } \\
\text { gradient, } \\
\text { Mg-precipitation }\end{array}$ & 13.4 & & & & 6.1 & 7.3 & & $(15)$ \\
\hline Barley & $\begin{array}{l}\text { Triton, sucrose } \\
\text { gradient, } \\
\text { Mg-precipitation }\end{array}$ & 7.8 & .2 & .04 & .71 & 3.0 & 4.8 & .24 & this work \\
\hline Spinach & $\begin{array}{l}\text { SDS-PAGE, gel } \\
\text { filtration }\end{array}$ & 2.1 & .004 & .01 & .02 & 1.1 & 1.3 & .01 & $\begin{array}{l}\text { calculated } \\
\text { from (66) }\end{array}$ \\
\hline Spinach & $\begin{array}{l}\text { Triton, propylene } \\
\text { glycol phase parti- } \\
\text { tioning }\end{array}$ & 5.7 a) & .006 & .02 & .12 & 2.5 & 3.2 & .03 & (49) \\
\hline \multicolumn{10}{|c|}{ Chlorophyll $a$-protein I } \\
\hline Spinach & $\begin{array}{l}\text { SDS-PAGE, gel- } \\
\text { filtration }\end{array}$ & 14.3 & .01 & 0 & .1 & 1.1 & 13.2 & .97 & $\begin{array}{l}\text { calculated } \\
\text { from (49) }\end{array}$ \\
\hline Swiss Chard & $\begin{array}{l}\text { Digitonin frac- } \\
\text { tionation column } \\
\text { chrom., sucrose } \\
\text { gradient }\end{array}$ & $50 \mathrm{~b})$ & 0 & 0 & 0 & 1 & 49 & 6 & (9) \\
\hline
\end{tabular}

a) Calculated from date in (23)

b) Photosystem I preparation composed of 5 major polypeptides 


\subsection{Pigment analysis of photosynthetic mutants}

The pigment profiles of three photosynthetic mutants are indicated on Figure 4. The mutant chlorina- 2 is photosynthetically competent but contains no chlorophyll $b$ (12). Electrophoretic analysis show the absence of chlorophyll $a / b$-proteins 1 and 2 in the mutant thylakoids (35). Chlorophyll $a / b$-protein 2 comprises approximately $50 \%$ of the total chlorophyll of the thylakoids and moreover binds carotenoids, mainly lutein and neoxanthin (Table III). In agreement with this, the pigment analysis of the mutant revealed the absence of chlorophyll $b$ and decreased levels of the xanthophylls (Table VI).

The mutant viridis- $z d^{69}$ is devoid of photosystem II activity (44) and lacks chlorophyll $a$ proteins 2 and 3. A previous study revealed that at least one of these chlorophyll proteins contain $\beta$-carotene (49). This may explain the low $\beta$-carotene content observed in the mutant thylakoids (Table VI). The decreased levels of neoxanthin and violaxanthin would suggest that these two xanthophylls are also bound to chlorophyll $a$ proteins 2 and/or 3 .

The third mutant investigated is viridis-z $b^{63}$. This mutant is devoid of photosystem I activity and lacks the $P 700$ containing reaction centre polypeptide chlorophyll $a$-protein 1 in addition to three low molecular weight polypeptides believed to carry iron-sulfur centres of photosystem I (30). The pigment analysis revealed a chlorophyll $a$ to $b$ ratio of the mutant thylakoids of 5.98 (Table VI). The spectrophotometrically determined ratio was 5.26 (30). Although the mutant thylakoids are enriched in chlorophyll $a$ protein 2 and $3(30)$, this by itself does not seem sufficient to produce the observed high chlorophyll $a / b$ ratio. It seems most likely that the light-harvesting complex of this mutant has a lowered capacity to bind chlorophyll $b$. $\beta$-Car-

Table VI.

Pigment composition of three barley mutants. otene is a component of both chlorophyll $a$-protein 1 and of chlorophyll $a$-proteins 2 and/or 3 (49). Since the former of these is lacking in the mutant whereas the latter two are enriched, the overall effect on the $\beta$-carotene content is difficult to predict. The analysis shows a decreased content of $\beta$-carotene in the mutant thylakoids. The xanthophyll content is very low. The absence of photosystem I associated polypeptides thus results in a decrease in the capacity of the mutant to bind xanthophylls.

In the analysis of the mutant thylakoids, additional peaks were observed. Thus chromatograms of viridis-zd $d^{69}$ showed an additional component eluting between violaxanthin and lutein. This component has been tentatively identified as lutein epoxide. The shoulder appearing after the principal chlorophyll $a$ peak represents pheophytin $a$.

\subsection{Acyl lipid composition of photosystem II vesicles and of photosystem I containing stroma lamellae}

The acyl lipid composition of the total lamellar systems, photosystem II vesicles and stroma lamellae are shown in Table VII. For comparative purposes literature data on the acyl lipid composition of lamellar systems and isolated chlorophyll-proteins are also included. The barley lamellar systems contain $3.7 \mu$ moles acyl lipid per mg chlorophyll $a$. This value (Table VII) corresponds well with data in the literature (22, 52). The lamellar systems of barley contained high amounts of monogalactosyldiglyceride (MG) and digalactosyldiglyceride (DG) as was also reported for spinach (Table VII) and a number of other plant species $(5,8,13,25,36,51,52$, $65,74)$. The levels of sulfoquinovosyldiglyceride (SL), phosphatidylglycerol (PG) and phosphatidylcholine $(\mathrm{PC})$ were also similar to those

\begin{tabular}{|c|c|c|c|c|c|c|c|}
\hline \multirow{2}{*}{$\begin{array}{l}\text { Lamellar } \\
\text { systems of }\end{array}$} & \multicolumn{6}{|c|}{ Pigment (molecules of pigment/1000 molecules of chlorophyli) } & \multirow{2}{*}{$\begin{array}{c}\text { ratio of } \\
\text { chlorophyll } \\
a \text { to } b\end{array}$} \\
\hline & neoxanthin & violaxanthin & lutein & chlorophyll & $1 b$ chlorophyll $a$ & $\beta$-carotene & \\
\hline wild-type & 39 & 43 & 70 & 215 & 785 & 65 & 3.65 \\
\hline chlorina- $f 2$ & $<5$ & 20 & 58 & 0 & 1000 & 74 & $\infty$ \\
\hline viridis-zd69 & 12 & 21 & 70 & 247 & 753 & 21 & 3.04 \\
\hline viridis-zb63 & $<5$ & 8 & 31 & 143 & 855 & 27 & 5.98 \\
\hline
\end{tabular}




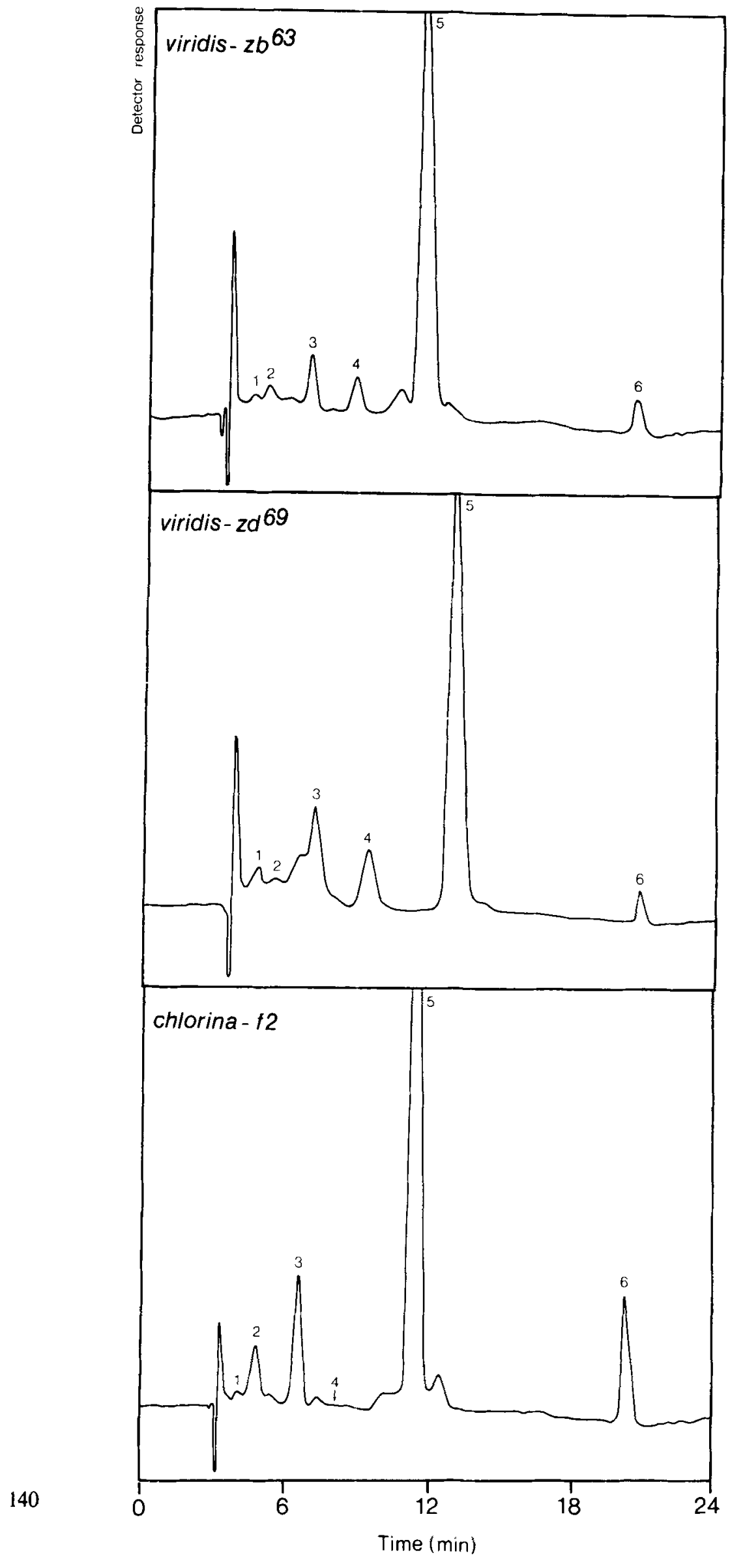


L. E. A. HENRY et al.: Lipid analyses of photosynthetic membranes.

Figure 4. High performance liquid chromatograms of the pigments in the thylakoids of the nuclear gene mutants viridis-z $b^{63}$, viridis-zd69, and chlorina-f2.

Detector sensitivity was set at 0.2 absorbance units. $1=$ neoxanthin, $2=$ violaxanthin, $3=$ lutein, $4=$ chlorophyll $b, 5=$ chlorophyll $a, 6=\beta$-carotene. Chromatographic conditions are described under 2.4 .

reported for spinach lamellar systems $(49,52)$, although in the study of RYRIE et al. (52) the SL content was almost three-fold higher.

The total acyl lipid content of the photosystem II and stroma lamellae vesicles was 2.4 and 4.6 $\mu$ moles of acyl lipid $\mathrm{mg}^{-1} \mathrm{chl} a$, respectively. Earlier studies revealed that the total acyl lipid content of the intact lamellar systems was similar to those of stroma lamellae and grana enriched fractions $(1,74)$. Polypeptide analysis as well as photochemical characterization of the photosystem II and the stroma lamellae vesicles used in this study revealed that a complete separation of the photosystems was accomplished (27). This clearly distinguishes these preparations from those earlier used and their acyl lipid content may therefore also be expected to differ $(1,74)$.

As for the lamellar systems, the constituent lipid classes of the stroma lamellae and the photosystem II vesicles were also analyzed by TLC and GLC. Compared to the lamellar systems, the stroma lamellae revealed a $73 \%$ decrease in the MG content and a minor reduction in the content of DG and PG. In contrast, a one-fold increase in the SL content was observed. Analysis of the photosystem II vesicles showed that their levels of MG, DG, and PG were reduced by 85 , 55 , and $70 \%$, respectively, whereas their SL content was unaltered. The reductions in the major lipid classes of stroma lamellae and photosystem II vesicles coincided with an increase in the amounts of unknown acyl lipids (Table VII). Thus, when the lamellar systems were analyzed and quantitated by TLC and GLC, the recovery of the acyl lipids in the known lipid classes was close to $100 \%$, whereas the recovery was only 44 and $45 \%$ for stroma lamellae and photosystem II vesicles, respectively. Some unknown lipids were very polar with chromatographic mobilities similar to those of PI and PC in the TLC system using acetone:benzene:water $(90: 30: 8(\mathrm{v} / \mathrm{v} / \mathrm{v}))$ as the developing solvent. Consequently, whereas PI and PC comprised only $0.24 \mu$ moles acyl lipid $\mathrm{mg}^{-1} \mathrm{Chl} a$ in the lamellar systems, the amounts of PI and PC plus the unknowns were 1.24 and $1.36 \mu$ moles $\cdot \mathrm{mg}^{-1} \mathrm{Chl} a$ in the stroma lamellae and photosystem II vesicles, respectively. A second class of the unknown lipids were very hydrophobic. They were separated from the other acyl lipids using the less polar solvent system hex-

Table VII.

Acyl lipid content of different chloroplast membrane fractions and isolated chlorophyll-proteins from various plant species.

\begin{tabular}{llcccccccc}
\hline & & \multicolumn{6}{c}{ acyl lipids $\mu$ moles $\cdot \mathrm{mg}^{-1}$ chlorophyll $a$} \\
\cline { 4 - 10 } Plant & Materials & Total & MG & DG & SL & PG & PC & Othersa & Reference \\
\hline Barley & Lamellar systems & 3.69 & 1.66 & 1.19 & .19 & .40 & .16 & .09 & this work \\
& PS II vesicles & 2.36 & .25 & .53 & .16 & .12 & & 1.3 & this work \\
& Stroma lamellae & 4.65 & .44 & .94 & .38 & .29 & & 2.6 & this work \\
Spinach & Chloroplasts & 4.18 & 2.17 & 1.08 & .72 & .21 & & & $(52)$ \\
& Chlorophyll $a / b$-protein 2 & 1.57 & .83 & .41 & .23 & .10 & & & $(52)$ \\
Spinach & Chlorophyll $a / b$-protein 2 & 0.95 & .31 & .26 & .12 & .14 & .06 & .06 & $(49)$ \\
& Chlorophyll $a$-protein 1 & 0.53 & 0 & 0 & .39 & 0 & 0 & .14 & $(49)$ \\
Spinach & Lamellar system & 2.73 & 1.42 & .73 & .20 & .25 & .09 & .04 & $(22)$ \\
Tobacco & Chlorophyll $a$-protein 1 & 0.016 & .01 & .003 & .002 & .001 & & & $(69)$ \\
& Chlorophyll $a / b$-protein 2c & 0.126 & .08 & .018 & .026 & .002 & & & $(69)$ \\
\hline
\end{tabular}

a) Include phosphatidyl inositol, free fatty acids and unknowns

b) Data calculated on basis of chlorophyll $a+b$

c) The data for the dissociated chlorophyll $a / b$-protein 2 were combined 
ane:acetone $(60: 40(\mathrm{v} / \mathrm{v}))$. The known acyl lipids remained at or close to the origin, whereas the various prenyl pigments were well resolved (49). When total lamellar systems were analyzed using this less polar solvent system no acyl lipids migrated with the pigments. When an identical separation was carried out using stroma lamellae or photosystem II vesicles, an appreciable quantity of acyl lipids migrated with some of the pigments. The amounts were 1.41 and $0.99 \mu$ moles acyl lipid $\mathrm{mg}^{-1} \mathrm{chl} a$, respectively. A major component of these hydrophobic acyl lipids has been identified as free fatty acids, but additional unidentified lipids were also present. These observations strongly indicate that the decreased levels of $\mathrm{MG}, \mathrm{DG}$, and $\mathrm{PG}$ observed in the stroma lamellae and the photosystem II vesicles are a result of an extensive lipolytic degradation of these lipid classes.

The fatty acid composition of the individual acyl lipids from lamellar systems, stroma lamellae and photosystem II vesicles revealed only minor differences (Table VIII): As compared with the lamellar systems, the stroma lamellae and the photosystem II vesicles had a higher content of palmitic acid in MG and DG, whereas their $\alpha$-linolenic acid content was lower. These differences may be the result of lipolytic activities. Lipases from runner beans (54) specifically hydrolyze the polyunsaturated galactolipids but were inactive towards saturated galactolipids. The linoleic acid content in PG of the stroma lamellae is twice that found in the lamellar systems and the photosystem II vesicles. These data are in agreement with the results obtained previously in barley $(6,13,65)$ and wheat (8). The $\alpha$-linolenic acid content of the MG in the present analysis amounted to $94 \%$. As expected, the ratio of the palmitic acid and the $\alpha$ linolenic acid levels in SL and PG was much higher than that of the galactolipids $(5,8,13,25$, 65). Trans-3-hexadecenoic acid was present only in PG (Table VIII) with a relative percent distribution comparable to that of greening barley $(5,57,65)$. The level is one half that reported for PG in light grown barley (13) and wheat (8). The low level of trans-3-hexadecenoic acid in the present analysis is most likely due to the low light intensity (1700 lux) at which the barley plants have been grown. Greening of dark grown barley seedlings at high light intensities for only twelve hours is reported to increase the relative level of trans-3-hexadecenoic acid in PG from 5 to $27 \%$ (57) and therefore results in a distribution similar to that of light grown barley (13) and wheat (8). It was earlier suggested that trans-3-hex-

Table VIII.

Fatty acid composition of lamellar system, stroma lamellae and photosystem II vesicles.

\begin{tabular}{|c|c|c|c|c|c|c|c|}
\hline \multirow[t]{2}{*}{ Membranes } & & \multicolumn{6}{|c|}{ Percentage of total fatty acids } \\
\hline & & $16: 0$ & $16: 1$ & $18: 0$ & $18 ; 1$ & $18: 2$ & $18: 3 a)$ \\
\hline \multirow{4}{*}{$\begin{array}{l}\text { Lamellar } \\
\text { system }\end{array}$} & $\mathrm{MG}$ & 1.5 & 0.1 & 0.1 & 0.3 & 4.0 & 93.9 \\
\hline & DG & 12.5 & $\mathrm{tr}^{\mathrm{b}}$ & 0.8 & 1.2 & 3.5 & 82.0 \\
\hline & SL & 45.7 & $\operatorname{tr}$ & 0.8 & 1.4 & 4.4 & 47.7 \\
\hline & PG & 35.1 & $11.6 \mathrm{c}$ & 0.8 & 2.7 & 10.2 & 39.6 \\
\hline \multirow{4}{*}{$\begin{array}{l}\text { Stroma } \\
\text { lamellae }\end{array}$} & $\mathrm{MG}$ & 5.0 & $\operatorname{tr}$ & 0.4 & 0.6 & 5.5 & 88.5 \\
\hline & $\mathrm{DG}$ & 18.0 & - & 1.2 & 2.2 & 7.6 & 71.1 \\
\hline & SL & 33.2 & 2.0 & 1.1 & 2.3 & 14.3 & 47.1 \\
\hline & PG & 32.1 & $7.3 \mathrm{c}$ & 1.3 & 2.9 & 23.2 & 33.1 \\
\hline \multirow{4}{*}{$\begin{array}{l}\text { Pholosystem II } \\
\text { vesicles }\end{array}$} & $\mathbf{M G}$ & 7.0 & $\operatorname{tr}$ & 0.8 & 0.9 & 4.7 & 86.9 \\
\hline & $\mathrm{DG}$ & 15.0 & $\mathrm{tr}$ & 1.0 & 1.8 & 4.5 & 77.7 \\
\hline & SL & 39.4 & $\operatorname{tr}$ & 0.8 & 1.5 & 6.5 & 51.7 \\
\hline & PG & 35.7 & $8.2 c$ & 1.3 & 3.0 & 9.9 & 41.9 \\
\hline
\end{tabular}

a $16: 0=$ palmitic acid; $16: 1=$ hexadecenoic acid; $18: 0=$ stearic acid; $18: 1=$ oleic acid; $18: 2=$ linoleic acid; $18: 3=x$ linolenic acid.

$\mathrm{b}_{\mathrm{tr}}=\leqslant 0.1 \%$

c 3-trans-hexadecenoic acid 
adecenoic acid has a specific function in grana stacking (67). This suggestion is not in agreement with the present results which demonstrate that the stroma lamellae which do not participate in stacking contain higher amounts of PG and trans-3-hexadecenoic acid than the photosystem II vesicles (Tables VII and VIJI).

\section{DISCUSSION}

The pigment analysis here reported was carried out by using reversed-phase HPLC. Other methods such as thin-layer chromatography (32, $34,50)$, paper chromatography (18), and normal-phase HPLC (48) have also been employed. However, reversed-phase HPLC seems superior to these methods with respect to stability of the pigments during analysis, resolution capacity, and analysis time. Analysis of plant pigments using reversed-phase HPLC has earlier been carried out $(48,55)$. The separation method here used is comparable to that reported in (48) with respect to time per analytic run but superior with respect to the separation of the more polar pigments and thus permits accurate automatic quantitation of each individual pigment. Furthermore, the $\mathrm{C}_{18}$ reversed-phase column here used is relatively cheap. By varying the gradient profile, the study of preparations containing additional pigments such as intermediates in chlorophyll biosynthesis should be possible. A chemically new chlorophyll species has recently been isolated from spinach (21). This chlorophyll absorbs at longer wavelengths and is attributed to P700. Based on the data presented by DöRnEMANN and SENGER (21) the elution time of this chlorophyll in the reversed-phase system here used would be predicted to be only very slightly shorter than that of chlorophyll $a$. Most likely, this chlorophyll species was not separated from chlorophyll $a$ in this study or was present in too low amounts to be detected.

Several methods have been reported for the fractionation of the thylakoid lamellar systems. Preparations enriched in stroma lamellae and grana stacks can be obtained by passing the lamellar systems through the French pressure cell or by digitonin treatment $(1,11,46,53,71$, 74). These preparations were found to be enriched with respect to photosystem I and II ac- tivity, respectively. An alternative to these studies is detergent fractionation of the lamellar systems. Using Triton X-100 as detergent, chlorophyll $a / b$-protein 2 can be isolated (15) and photosystem I particles containing only few polypeptides have been obtained $(9,30,41)$. Using stronger detergents like SDS, the thylakoid membrane can be fractionated by SDS-polyacrylamide gel electrophoresis. Pigment and acyl lipid containing bands can be cut out directly from the gels and analyzed $(67,68,69)$. The approach using detergents have however produced variable results (Tables V and VII). One reason may be that the preparations compared have not always been identical with respect to their polypeptide content. Secondly, a differential displacement of the non-covalently bound pigments and acyl lipids with detergent molecules may have occurred. For the pigments, this is most clearly illustrated by the reported pigment composition of chlorophyll $a / b$-protein 2 (Table $\mathrm{V})$. The reported number of chlorophyll molecules attached to the protein varies from 2 to 13 , and the neoxanthin, violaxanthin, and lutein determinations differ by factors higher than 100 , 25 , and 50 , respectively.

A similar situation applies for the data on the acyl lipid content of different membrane preparations and isolated chlorophyll proteins. $P 700$ chlorophyll $a$-protein 1 is the only chlorophyll protein present in the stroma lamellae preparation used in this study. Its acyl lipid content has been determined by two independent methods $(49,69)$. RAWYLER et al. (49) isolated chlorophyll a-protein 1 from spinach using Triton $\mathrm{X}-100$ as detergent and hydroxyapatite chromatography (Table VII). The isolated chlorophyll-protein was found to contain only sulfoquinovosyldiglycerides and phosphatidylinositol. Interestingly the amount of SL present was identical to the content found in the stroma lamellae vesicles. Tremoliere et al. (69) purified $P 700$ chlorophyll $a$-protein 1 from Nicotiana tabaccum. The lamellar systems were solubilized by treatment with SDS and the chlorophyll-proteins separated by SDS-PAGE. Less than $0.5 \%$ of the total lipids present in the lamellar systems were retained in this chlorophyll-protein after electrophoresis. This level is 32 times smaller than that observed by RAWYLER et al. (49). 
The acyl lipid content of chlorophyll $a / b$-protein 2 isolated from spinach by two independent methods has been reported $(49,52)$. Both preparations reveal a remarkable conservation of the relative distribution of the various lipid classes compared to the lamellar systems (Table VII). Whereas the amounts of PG are about the same in the two preparations, the acyl lipid content of the remaining lipid classes is doubled in chlorophyll $a / b$-protein 2 prepared with Triton X-100 (52) compared to the preparation obtained with the combined use of Triton X-100 and polypropylene glycol (49). This observation and use of polypropylene points towards detergent effect of polypropylene glycol. A similar situation could then apply for polyethyleneglycol which was used in the present study in the preparation of the photosystem II vesicles. This would explain the observed unexpected depletion of the total lipid content of the photosystem II vesicles compared to stroma lamellae (Table VII). Chlorophyll $a / b$-protein 2 was also isolated from tobacco using SDS-PAGE (69). The lipid content of this preparation is 6-11 times smaller than that reported above and could even represent contamination by the tailing peak of lipids present in the free chlorophyll band. From the discussion above it is thus apparent that a direct comparison of the pigment and acyl lipid content of an isolated protein with that of a non-detergent fractionated membrane preparation is difficult although the protein analysed could be the only or a major constituent of the membrane preparation. However, the differential loss of pigments and acyl lipids observed using the various detergents may eventually lead to a better understanding of the organization of the various pigments and acyl lipids in the chlorophyll-proteins. One interesting result in this direction is the specific retainment of the sulfoquinovosyldiglycerides in chlorophyll $a$-protein 1 indicating a tight binding of these to chlorophyll $a$-protein 1 .

The fractionation procedure used in the present study was described previously (27) and is based on the observation, that under conditions of strong stacking, a complete separation of the two photosystems can be accomplished. Initial treatment in a French pressure cell followed by differential centrifugation produced a stroma lamellae preparation enriched in photosystem I activity and without photosystem II activity. Further fractionation of the grana material by repeated phase-partitioning permitted the isolation of an inside-out photosystem II vesicle devoid of photosystem I components. The three photosystem I associated polypeptides (30) are major components of the stroma lamellae vesicles, but in addition these contain other stroma lamellae associated components like the chloroplast coupling factor. They are, however, devoid of chlorophyll $a / b$-protein 2 (27). The photosystem II vesicles have a simple well defined polypeptide composition (28). It could therefore be expected that pigment and acyl lipid analysis of these two fractions would allow a specific assignment of individual acyl and prenyl lipids to the two photosystems. The analyses here reported indeed reveal some significant differences. However, whereas SDS-PAGE separation of the thylakoid polypeptides resolves at least 50 different polypeptides characteristic for either appressed or non-appressed membrane regions, the number of characterized acyl and prenyl lipids of the thylakoids is comparatively much more simple. The results reveal that none of the six major pigments or any of the major lipid classes are associated exclusively with one of the two photosystems. The method used do not permit analysis of individual thylakoid polypeptides, but only of the overall composition of a set of thylakoid polypeptides. An association of one pigment with a specific polypeptide within this set of polypeptides may very well be masked by the absence or presence of other acyl or prenyl lipid binding polypeptides.

The three mutants chlorina- $f$, viridis-zd69, and viridis-z $z b^{63}$ were selected because they lack the chlorophyll $a / b$-proteins, chlorophyll $a$-proteins 2 and 3 , and chlorophyll $a$-protein 1, respectively $(30,44,62)$. These constitute the three main chlorophyll-protein complexes of the photosynthetic membrane, although they contribute to a varying extent to the total amount of chlorophyll in the thylakoids. On a chlorophyll basis, the photosynthetic mutants generally show a reduced carotenoid content, the only two exceptions being the increased level of $\beta$-carotene in chlorina- $f 2$ and the unaltered level of lutein in viridis- $z d^{69}$. 
Analysis of the acyl lipids of the photosystem II vesicles and the stroma lamellae vesicles revealed the presence of high amounts of free fatty acid plus unknown lipids not present in the original lamellar systems. These components are formed by lipolytic degradation and/or transformations of MG, DG, and PG. The presence of active lipolytic enzymes have been demonstrated in many plant species $(3,5,24,37,54,58,61)$. A highly active galactolipid lipase has been purified from Phaseolus vulgaris chloroplasts. SHaw et al. (58) demonstrated that this lipase when incubated with spinach chloroplast membranes in the presence of bovine serum albumin hydrolyses $30 \%$ of $\mathrm{MG}$ and $50 \%$ of $\mathrm{DG}$ and $\mathrm{PC}$. The content of SL and PG was unaltered. The electron flow through photosystem I and photosystem Il using artificial electron donors and acceptors was not affected by this lipase treatment, whereas oxygen evolution and photophosphorylation were partially inhibited. When bovine serum albumin was omitted from the incubation mixture the lipase removed $91 \%$ of $\mathrm{MG}, 83 \%$ of DG, and all of PC, whereas SL was unaltered. Under such conditions, a nearly total inhibition of all photochemical activities was achieved. It was concluded that the inhibition was due to the released free fatty acids, primarily $\boldsymbol{a}$-linolenic acid. Bovine serum albumin exerts its protective effect by binding the liberated fatty acids. In the present studies a similar action by a chloroplast localized lipase or acyltransferase $(19,20,26)$ can be responsible for the observed degradation and transformations of the acyl lipids in the stroma lamellae and the photosystem II vesicles. These lipases or acyl transferases may be compartmentalized and only have a limited access to their substrates in the lamellar systems. Upon mechanical disruption within the French pressure cell, this protection is abolished. The pronounced degradation of the stroma lamellae and the photosystem II vesicles are also favoured by the long time required for their preparation ( 3 and 8 hours, respectively) compared to the lamellar systems (0.5 hours) $(29,61)$. Despite the fact that no bovine serum albumin or other protective reagents were added to trap the released free fatty acids, the stroma lamellae and photosystem II vesicles showed high photochemical rates (27):
The rate of oxygen evolution of the photosystem II vesicles was higher than that of the unfractionated lamellar systems, and the photosystem I activity of the stroma lamellae was doubled although more than $50 \%$ of the acyl lipids composing both the stroma lamellae and the photosystem II vesicles have been hydrolyzed or severely modified. However, acyl lipids more tightly bound to the pigment proteins may be protected towards modification and degradation and be essential to obtain photochemical activity.

\section{ACKNOWLEDGEMENTS}

Professor D, vON WETtSTeIN is thanked for constructive comments and for reviewing the manuscript. Inga Olsen, Nina Rasmussen, and HaNNe Them Nielsen are thanked for technical assistance. This work was supported by a longterm EMBO post doctoral fellowship to L.E.A. HENRY and by the Commission of the European Communities, Contract No. ESD.013-DK of the Solar Energy Programme.

\section{REFERENCES}

1. AlLen. C.F., P. GoOD, T. Trosper \& R.B. PARK: Chlorophyll, glycerolipid and protein ratios in spinach chloroplast grana and stroma lamellae. Biochem. Biophys. Res. Commun. 48, 907-913 (1972)

2. ANDERSON, J.M.: Chlorophyll-protein complexes of higher plant thylakoids: Distribution, stoichiometry and organization in the photosynthetic unit. FEBS Lett. 117, 327-331 (1980)

3. ANDERSON, M.M., R.E. MCCARTY \& E.A. ZIMMER: The role of galactolipids in spinach chloroplast lamellar membranes. Plant Physiol. 53, 699-704 (1974)

4. ANDERSSON, B. \& J.M. ANDERSON: Lateral heterogeneity in the distribution of chlorophyllprotein complexes of the thylakoid membranes of spinach chloroplasts. Biochim. Biophys. Acta 593, 427-440 (1980)

5. APPelqvist, L.Å., P.K. STumpF \& D. von WetTSTEIN: Lipid synthesis and ultrastructure of isolated barley chloroplasts. Plant Physiol. 43, 163-187 (1968)

6. APPelqVist, L.A., J.E. Boynton, P.K. StumpF \& D. VON WETTSTEIN: Lipid biosynthesis in relation to chloroplast development in barley. $J$. Lipid Res. 9, 425-436 (1968) 
7. Avato, P., J.D. Mikkelsen \& P. von WettSTEIN-KNOWLES: Synthesis of epicuticular primary alcohols and intracellular fatty acids by tissue slices from cer-j59 barley leaves. Carlsberg Res. Commun. 47, 377-390 (1982)

8. Bahl, J., B. Francke \& R. Monéger: Lipid composition of envelopes, prolamellar bodies and other plastid membranes in etiolated, green and greening wheat leaves. Planta (Berl.) 129, 193-201 (1976)

9. Bengis, C. \& N. Nelson: Purification and properties of the photosystem I reaction center from chloroplasts. J. Biol. Chem. 250, 2783 2788 (1975)

10. BeRThOLd, D.A., G.T. BabCock \& C.F. YoCum: A highly resolved, oxygen-evolving photosystem II preparation from spinach thylakoid membranes. EPR and electron-transport properties. FEBS Lett. 134, 231-234 (1981)

11. BOARDMAN, N.K. \& J.M. ANDERSON: Isolation from spinach chloroplasts of particles containing different proportions of chlorophyll $a$ and chlorophyll $b$ and their possible role in the light reactions of photosynthesis. Nature (London) 203, 166-167 (1964)

12. Botrdman, N.K. \& H.R. Highkin: Studies on a barley mutant lacking chlorophyll b. I. Photochemical activity of isolated chloroplasts. Biochim. Biophys. Acta 126, 189-199 (1966)

13. Bolton, P., J. Wharfe \& J.L. Harwood: The lipid composition of a barley mutant lacking chlorophyll $b$. Biochem. J. 174, 67-72 (1978)

14. Broglie, R., G. Bellemare, S.G. Bartlett, N.-H. Chua \& A.R. Cashmore: Cloned DNA sequences complementary to mRNA encoding precursors to the small subunit of ribulose-1.5bisphosphate carboxylase and a chlorophyll a/ $b$-binding polypeptide. Proc. Natl. Acad. Sci. USA 78, 7304-7308 (1981)

15. Burke, J.J., C.L. DitTo \& C.J. Arntzen: Involvement of the light-harvesting complex in cation regulation of excitation energy distribution in chloroplasts. Arch. Biochem. Biophys. $187,252-263$ (1978)

16. Chiba, Y., I. Aiga, M. Ioemori, Y. Satoh, K. Matsushita, T. Sasa: Studies on chlorophyllase of Chlorella protothecoides. I. Enzymic phytylation of methyl chlorophyllide. Plant Cell Physiol. 8, 623-635 (1967)

17. Coruzzi, G., R. Broglie, A. Cashmore \& N.H. ChuA: Nucleotide sequences of two pea cDNA clones encoding the small subunit of ribulose 1.5-bisphosphate carboxylase and the major chlorophyll a/b-binding thylakoid polypeptide. J. Biol. Chem. 258, 1399-1402 (1983)
18. Davies, B.H.: Carotenoids. In: Chemistry and Biochemistry of Plant Pigments Vol.2 (T.W. Goodwin ed.) Academic Press, New York, San Francisco and London pp. 38-165 (1976)

19. DeCKer, M. \& W. TANNER: Rapid release of free fatty acids during cell breakage and their effects on a sugar-proton cotransport system in Chlorella vulgaris. FEBS Lett. 60, 346-348 (1975)

20. Dorne, A.-J., M.A. Block, J. Joyard \& R. DoucE: The galactolipid: galactolipid galactosyltransferase is located on the outer surface of the outer membrane of the chloroplast envelope. FEBS Lett. 145, 30-34 (1982)

21. Dörnemann, D. \& H. Senger: Physical and chemical properties of chlorophyll RCI extracted from photosystem I of spinach leaves and from green algae. Photochem. Photobiol. 35, $821-826$ (1982)

22. Douce, R., R.B. Holtz \& A.A. Benson: Isolation and properties of the envelope of spinach chloroplasts. J. Biol. Chem. 248, 7215-7222 (1973)

23. FoYer, C.H. \& D.O. Hall: A rapid procedure for the preparation of light harvesting chlorophyll $a / b$ protein complex. An assessment of its manganese content. FEBS Lett. 101, 324-328 (1979)

24. Galliard, T:: Degradation of acyl lipids. Hydrolytic and oxidative enzymes. In: The Biochemistry of Plants. A Comprehensive Treatise. Lipids: Structure and function. (Stumpf, P.K. ed.) Acad. Press, New York, 5, pp. 85-116 (1980)

25. Harwood, J.L.: Plant Acyl Lipids: Structure, distribution, and analysis. In: The Biochemistry of Plants. A Comprehensive Treatise. Lipids: Structure and Function. (Stumpf, P.K. ed.) Acad. Press, New York, 5, pp. 1-55 (1980)

26. Heinz, E., M. Bertrams, J. Joyard \& R. DouCE: Demonstration of an acyltransferase activity in chloroplast envelopes. $Z$. Pflanzenphysiol. 87, 325-331 (1978)

27. Henry, L.E.A. \& B.L. Møller: Polypeptide composition of an oxygen evolving photosystem II vesicle from spinach chloroplasts. Carlsberg Res. Commun. 46, 227-242 (1981)

28. Henry, L.E.A., B.L. Møller, B. ANdersson \& H.-E. ÁKERLUND: Reactivation of photosynthetic oxygen evolution in Tris-inactivated inside-out photosystem II vesicles from spinach. Carlsberg Res. Commun. 47, 187-198 (1982)

29. Henry, L.E.A., R.J. Strasser \& P.-A. SiEGENTHALER: Alteration in the acyl lipid com- 
position of thylakoids induced by aging and its effect on thylakoid structure. Plant Physiol. 69, 531-536 (1982)

30. Hiller, R.G., B.L. Møller \& G. HøyerHANSEN: Characterization of six putative photosystem I mutants in barley. Carlsberg Res. Commun. 45, 315-328 (1980)

31. HoLten, M.: Chlorophylls. In: Chemistry and Biochemistry of Plant Pigments Vol.2 (T.W. Goodwin ed.) Academic Press, New York, San Francisco and London pp. 1-37 (1976)

32. Iriyama, K., M. Yoshiura, M. Shiraki, S. YANO \& S. SAITO: An improved method for the rapid and easy separation of leaf pigments and their derivatives by thin-layer chromatography. Anal. Biochem. 106, 322-326 (1980)

33. KnafF, D.B., R. Malkin, J.C. Myron \& M. STOLLER: The role of plastoquinone and $\beta$-carotene in the primary reaction of plant photosystem II. Biochim. Biophys. Acta 459, 402411 (1977)

34. Lichtenthaler, H.K., K. Bonner \& C. LiLJENBERG: Separation of prenylquinones, prenylvitamins and prenols on thin-layer plates impregnated with silver nitrate. J. Chromatogr. 242, 196-201 (1982)

35. Machold, O., D.J. Simpson \& B.L. Møller: Chlorophyll-proteins of thylakoids from wildtype and mutants of barley (Hordeum vulgare L.) Carlsberg Res. Commun. 44, 235-254 (1979)

36. Mackender, R.O. \& R.M. LeeCh: The galactolipid, phospholipid, and fatty acid composition of the chloroplast envelope membranes of Vicia faba L. Plant Physiol. 53, 496-502 (1974)

37. MCCARTY, R.E. \& A.T. JaGendorf: Chloroplast damage due to enzymatic hydrolysis of endogenous lipids. Plant Physiol. 40, 725-735 (1965)

38. Metz, J.G., J. WONG \& N.I. Bishop: Changes in electrophoretic mobility of a chloroplast membrane polypeptide associated with the loss of the oxidizing side of photosystem II in low fluorescent mutants of Scenedesmus. FEBS Lett. 114, 61-66 (1980)

39. Metz, J.G. \& D. Miles: Use of nuclear gene mutant of maize to identify components of photosystem II. Biochim. Biophys. Acta 681, 95-102 (1982)

40. Møller, B.L., R.M. Smillie \& G. HøyerHansen: A photosystem I mutant in barley (Hordeum vulgare L.) Carlsberg Res. Commun. 45, 87-99 (1980)

41. Møller, B.L., G. Høyer-Hansen \& R.G. HILlER: Functional characterization of barley thylakoid polypeptides resolved by SDS-polyacrylamide gel electrophoresis. Photosynth., Proc. Int. Congr. 5th. 3, pp. 245-256 (1981)

42. Møller, B.L. J.H.A. Nugient \& M.C.W. Evans: Electron paramagnetic resonance spectrometry of photosystem I mutants in barley. Carlsberg Res. Commun. 46, 373-382 (1981)

43. NeTring, A. \& C. BARR: Design for an accurate and versatile radio gas chromatograph. Anal. Biochem. 84, 136-146 (1978)

44. Nielsen, N.C., K.W. Henningsen \& R.M. SMLLuE: Chloroplast membrane proteins in wild-type and mutant barley. Photosynth., Proc. Int. Congr. 3rd, 3, 1603-1614 (1974)

45. Okayama, S. \& W.L. Butler: Extraction and reconstitution of photosystem II. Plant Physiol. 49, 769-774 (1972)

46. PARK, R.B. \& P.V. SANE: Distribution of function and structure in chloroplast lamellae. Ann. Rev. Plant Physiol. 22, 395-430 (1971)

47. PoHL, P., H. Glasl \& H. WAGner: Zur Analytik pflanzlicher Glyko- und Phospholipoide und ihrer Fettsäuren. J. Chromatogr. 49, 488-492 (1970)

48. Prenzel, U. \& H.K. Lichtenthaler: Highperformance liquid chromatography of prenylquinones, prenylvitamins and prenols. J. Chromatogr. 242, 9-19 (1982)

49. Rawyler, A., L.E.A. Henry \& P.-A. SiEGENTHALER: Acyl and pigment lipid composition of two chlorophyll-proteins. Carlsberg Res. Commun. 45, 443-451 (1980)

50. Rawyler, A. \& P.-A. Siegenthaler: Rapid analysis of membrane lipids using a combination of thin-layer chromatography and scanning of photographic negatives. J. Biochem. Biophys. Methods 2, 271-281 (1980)

51. Roughan, P.G. \& R.D. BatT: The glycerolipid composition of leaves. Phytochem. 8, 363-369 (1969)

52. RYRIE, I.J., J.M. ANDERSON \& D.J. GOODCHILD: The role of the light-harvesting chlorophyll a/b-protein complex in chloroplast membrane stacking. Cation-induced aggregation of reconstituted proteoliposomes. Eur. J. Biochem. 107, 345-354 (1980)

53. Sane, P.V., D.J. Goodchil.d \& R.B. Park: Characterization of chloroplast photosystem 1 and 2 separated by a non-detergent method. Biochim. Biophys. Acta 216, 162-178 (1970)

54. SASTRY, P.S. \& M. Kates: Hydrolysis of monogalactosyl and digalactosyl diglycerides by specific enzymes in runner-bean leaves. Biochemistry 3, 1280-1287 (1964)

55. Schwartz, S.J. \& J.H. von Elbe: High perfor- 
mance liquid chromatography of plant pigments - a review. J. Liquid Chromatogr. 5, 4373 (1982)

56. Searle, G.F.W. \& J.S.C. Wessels: Role of $\beta$ carotene in the reaction centres of photosystems I and II of spinach chloroplasts prepared in non-polar solvents. Biochim. Biophys. Acta 504, 84-99 (1978)

57. Selidén, G. \& E. Selstam: Changes in chloroplast lipid during the development of photosynthetic activity in barley etio-chloroplasts. Physiol. Plant 37, 35-41 (1976)

58. Shaw, A.B., M.M. Anderson \& R.E. McCarTY: Role of galactolipids in spinach chloroplast lamellar membranes. Effects of galactolipid depletion on phosphorylation and electron flow. Plant Physiol. 57, 724-729 (1976)

59. Shiol, Y., R. Fukae \& T. SaSa: Chlorophyll analysis by high performance liquid chromatography. Biochim. Biophys. Acta 722, 7279 (1983)

60. Siebertz. H.P., E. Heinz. M. Linscheid, J. JoYaro \& R. DoucE: Characterization of lipids from chloroplast envelopes. Eur. J. Biochem. 101, 429-438 (1979)

61. Siegenthaler, P.-A., A. Rawyler \& L.E.A. HENRY: A new type of correlation between changes in lipid composition and loss of electron transport activities during aging in vitro. Photosynth., Proc. Int. Congr. 5th, 2, pp. 167174 (1981)

62. Simpson, D.J. \& D. von Wettstein: Macromolecular physiology of plastids. XIV. Viridis mutants in barley: Genetic, fluoroscopic and ultrastructural characterization. Carlsberg Res. Commun. 45, 283-314 (1980)

63. Sternberg, J.C., W.S. Gallaway \& D.T.L. JONES: The mechanism of response of flame ionization detectors. In: Proc. Instrument Soc. Amer. 3rd Int. Symp. on Gas Chromatogr. (N. Brenner, J.E. Callen \& M.D. Weiss eds.) Academic Press, New York, San Francisco and London pp. 231-267 (1962)

64. SVEC, W.A.: The isolation, preparation, characterization, and estimation of the chlorophylls and the bacterio-chlorophylls. In: The Porphyrins, Physical Chemistry Part C (D. Dolphin ed.) Academic Press, New York, pp. 341399 (1978)

65. Tevini, M.: Light, function and lipids during plastid development. In: Lipids and Lipid
Polymers in Higher Plants. (M. Tevini \& H.K. Lichtenthaler eds.) Springer-Verlag, Berlin, Heidelberg. pp. 121-145 (1977)

66. Thornber, J.P., J.C. Stewart, M.W.C. HatTON \& J.L. BAILEY: Studies on the nature of chloroplast lamellae. II. Chemical composition and further physical properties of two chlorophyll-protein complexes. Biochemistry 6, 2006-2014 (1967)

67. Trémolieres, A., T. Guillot-Salomon, J.-P. DubacQ, R. Jacques, P.Mazliak \& M. Signol: The effects of monochromatic light on $x$ linolenic and trans-3-hexadecenoic acid biosynthesis and its correlation to the development of the plastid lamellar system. Physiol. Plant. 45, 429-436 (1979)

68. Trémolieres, A., J.-P. Dubacq, F. AmbardBretTEVILle \& R. RÉmY: Lipid composition of chlorophyll-protein complexes. FEBS Lett. 130, 27-31 (1981)

69. Trémoliere, A., J.-P. Dubacq, J.-C. Duval, Y. LEMOINE \& R. RÉmY: Role of phosphatidylglycerol containing trans-hexadecenoic acid in oligomeric organization of the light-harvesting chlorophyll protein (LHCP). In: Biochemistry and Metabolism of Plant Lipids. J.F.G.M. Wintermanns \& P.J.C. Kuiper, eds., Elsevier/North Holland, Biomedical Press, Amsterdam pp. 369-372 (1982)

70. WALDI, D. voN: Sprühreagentien für die Dünnsschicht-chromatographie. In: Dünnschicht Chromatographie (E. Stahl ed.) Springer-Verlag, Berlin pp. 496-515 (1962)

71. Wessels, J.S.C.: Fragmentation. In: Encyclopedia of Plant Physiology, New Series. Photosynthesis I. A Trebst and M. Avron eds., Vol. 5 pp. 563-573 (1971)

72. Wettstein, D. von: Chloroplast and Nucleus: Concerted interplay between genomes of different cell organelles. The Emil Heitz Lecture. In: International Cell Biology 1980-1981. (H.G. Schweiger ed.) Springer-Verlag, Berlin, Heidelberg, pp. 250-272 (1981)

73. Wintermans, J.F.G.M. \& A. DE Mots: Spectrophotometric characteristics of chlorophylls $\mathrm{a}$ and $\mathrm{b}$ and their pheophytins in ethanol. Biochim. Biophys. Acta 109, 448-453 (1965)

74. WINTERMANNS, J.F.G.M.: On the galactolipid composition of subchloroplast fragments. Biochim. Biophys. Acta 248, 530-535 (1971) 